\title{
The Impact of Perceived Benefits and Risks on Current and Desired Levels of Outsourcing: Hotel Managers' Perspective
}

\begin{abstract}
The current paper investigates the interactions between perceived benefits and risks of outsourcing and outsourcing adoption from hoteliers' perspective. It is basically argued that, managers' perceived benefits and risks of outsourcing shape its adoption levels; both currently and in the future. Utilizing a representative sample of hotels in Egypt, the current study collected data from 123 hotels using a 32-hotel activity list. The results indicated that although managers' perceived benefits of outsourcing have a positive effect on the current level of outsourcing (CLO), it has indirect effect on the desired level of outsourcing (DLO). Interestingly, the results confirmed that the CLO mediates the relationship between managers' perceived benefits and DLO. Moreover, although the perceived risks of outsourcing moderate the relationship between CLO and DLO, the results were not significant. These findings have important implications for both theory and practice.
\end{abstract}

Keywords: hotel outsourcing, managers' perceived benefits/risks, current level of outsourcing, desired level of outsourcing

\section{Introduction}

Outsourcing of hotel activities has become an integral part of hotels' operation strategy with predictions for continued growth. This may be attributed on one hand to the broad range of activities undertaken in a hotel combined with the need to focus on core activities and sustain a competitive advantage (Espino-Rodríguez \& Ramírez-Fierro, 2018b; Espino-Rodríguez \& Gil-Padilla, 2005; Lam \& Han, 2005). While, on the other hand, outsourcing can lead to more efficient hotel operations by outsourcing selected activities to external specialist companies (Belcourt, 2006; Lamminmaki, 2005). Outsourcing is simply made up of two words 'out' or outside the firm and 'source' referring to the external provider of the service, which in business terms means that certain hotel activities are provided for the hotel by an external expert or 
professional company (Espino-Rodríguez \& Gil-Padilla, 2005). Having the same concept, Barthélemy (2003) defined outsourcing as "turning over all or part of an organizational activity to an outside vendor". In other words, the hotel decides to provide a service, either partially or in full, by transferring it to a specialized company. This study, therefore, defines outsourcing as an arrangement whereby a hotel depends on an outside entity to perform one or more of its activities.

By embarking into outsourcing, firms can offer better client service, produce a better product, and do a better job efficiently (Hamzah, Aman, Maelah, Auzair, \& Amiruddin, 2010). Further, outsourcing allows hotels to focus efforts on core competencies and strengthens their adaptability to the changing business environment (Lam \& Han, 2005). On the other side, outsourcing comes at a cost. The literature to date revealed numerous risks related to outsourcing (Dorasamy, Marimuthu, Jayabalan, Raman, \& Kaliannan, 2010; Hiamey \& Amenumey, 2013; Zhang, Ma, \& Qu, 2018). To this end, Espino-Rodríguez and RamírezFierro (2018b) speculated that outsourcing strategies, especially in chain hotels, may be enforced on hotel managers while the decisions to outsource are made at the corporate or director levels. Such strategies are not favored by operation managers unless they feel their benefits or perceive low risks. However, to date, little empirical evidence can be found regarding the actual role played by hotel managers in the operational level in shaping outsourcing decisions. To fill this gap, this study sets out with the aim of investigating the relationship between managers' perceived benefits of outsourcing and their impact on both current and desired levels of hotel outsourcing. In addition, it tests the moderating role of the managers' perceived risks on the relationship between current and desired levels of outsourcing. Furthermore, this study contributes to the literature about hotel outsourcing in two main ways. On one hand, it examines the role of operation managers in shaping both current and desired levels of outsourcing. On the other hand, it examines the interaction effects between levels of outsourcing and the perceived benefits and risks of outsourcing.

This paper proceeds as follow. The next section provides a review of the literature and proposes the conceptual model and hypotheses of the study. After that, the methods used to test the proposed model is presented and justified. Then, the results are presented for each 
hypothesis. Finally, we discuss and conclude with the theoretical and managerial implications of the study.

\section{Literature review}

The existing literature referred to various theories in explaining outsourcing. This paper, however, keeps focusing on two main theories relevant to the benefits and risks of outsourcing. These theories include the transaction cost economics (TCE: Williamson, 1981, 2008) and the Resource-based view (RBV: Barney, 2001). The former holds that outsourcing is an alternative to the inhouse provision of services. The key notion of transaction's efficiency guides the decision to make or buy. Efficiency, however, is contextualized and follows the state of specific attributes (Lamminmaki, 2003, 2005, 2007, 2011). The latter, however, viewed the company as a set of unique strategic resources that enables the creation of a sustainable competitive advantage. The RBV proposes that companies with fewer internal skills and resources are more likely to outsource (Espino-Rodríguez \& Padrón-Robaina, 2005). Consequently, outsourcing must be a result of the desire to obtain specific types of resources that the hotel does not possess, and which are provided more efficiently by third parties. In sum, the TCE theory perceives outsourcing as a method of cost reduction which might entail certain costs of transaction. While, the RBV considers outsourcing as a source of competitive advantage. To sum up, both theories play a significance role in highlighting the potential benefits and risks of outsourcing.

\subsection{Benefits of Hotel Outsourcing}

The literature revealed that outsourcing (can) provide firms with various economic, technological, and strategic benefits (Espino-Rodríguez \& Ramírez-Fierro, 2018a, 2018b; Lamminmaki, 2003, 2007, 2011; Letica, 2016). Based on the TCE, outsourcing can benefit the firm by providing a lower production cost compared to the inhouse production (Williamson, 1981). This is due to the specialism of the external service providers and their economies of scale (Gilley, Greer, \& Rasheed, 2004). On the other side, following the RBV logic outsourcing is seen as a strategic tool for gaining competitive advantage due to focusing on core activities while outsourcing the non-core activities to specialists, thus, the firm can do better with both core and non-core activities (Espino-Rodríguez \& Padrón-Robaina, 2005; Gilley \& Rasheed, 
2000). Empirically, scholars tried to understand the benefits of outsourcing in the hotel industry (e.g., Espino-Rodríguez \& Ramírez-Fierro, 2018; Hiamey \& Amenumey, 2013; Lamminmaki, 2008). For instance, outsourcing allowed hotels to focus on core activities, elasticity, specialism, endorsing swift growth, and evading capital expenditure (Lamminmaki, 2011; Sharma et al., 2015). Furthermore, in a dynamic and competitive environment, outsourcing permits swift adaptation if the hotel uses novel technologies, service advances, or innovations (Altin, Uysal, \& Schwartz, 2018). However, the literature about the outsourcing-performance link is not consistent. For example, although some studies supported the positive influence of outsourcing on performance (Elmuti, 2003; Tomás F Espino-Rodríguez \& Padrón-Robaina, 2005), other studies did not find any significant impact of outsourcing on hotel performance (Chatzoglou \& Sarigiannidis, 2009). Overall, Baytok, Soybali, and Zorlu (2013) classified the benefits of outsourcing into four categories. Their findings revealed that the most important benefits of outsourcing lie within increase in service and quality, administrative benefits, financial benefits and organizational benefits, respectively. Espino-Rodríguez, Lai, and Baum (2012) also indicated that the perceived benefits and risks of outsourcing can substantially influence the outsourcing strategy. Thus, this study postulates that the perceived benefits of outsourcing determine the level of current outsourcing in hotels. In other words, the higher the managers' perceived benefits, the higher will be the level of outsourcing. This argument is proposed in the following hypothesis:

Hypothesis 1. Managers' perceived benefits of outsourcing are positively related to current levels of outsourcing.

\subsection{Levels of Hotel Outsourcing}

Outsourcing can be classified into types following different criteria (Espino-Rodríguez \& Padrón-Robaina, 2004; Gilley et al., 2004; Green, Chakrabarty, \& Whitten, 2007; Power, 2006; Rothery, 1995). However, this study focuses on the level of outsourcing in terms of range (total versus partial outsourcing) and temporal (current versus future outsourcing). Outsourcing can be classified based on its range as total outsourcing or partial outsourcing (Espino-Rodríguez \& Padrón-Robaina, 2004). The total outsourcing indicates that a large part of an enterprise 
activity, for example, the logistics, is transferred to another company. In this case, the external service provider takes over the staff, trucks, also hardware and software as well as contractual obligations from the enterprise (Wieske, 2018). Consequently, total outsourcing means transferring an entire process or department (Jeffay, Bohannon, \& Laspisa, 1997). For instance, a hotel may fully outsource its human resource department, security, or F\&B by depending on an external company to manage the whole operation. On the other hand, partial outsourcing means undertaking activity-specific outsourcing in which, specific activities are outsourced while keeping the rest of the department in-house. For instance, a hotel may outsource laundry while keeping the rest of the house keeping activities in-house (Hiamey \& Amenumey, 2013). Furthermore, with partial outsourcing, not the whole subranges of a group (e.g. transport services, logistics, IT) are divided. An exterior services provider will condense simply definite duties. The outcomes are substantial rises of yield, as well as the opportunity to be able to swiftly change the outsourcing partner in case of service problems (Wieske, 2018). Accordingly, hotel managers decide whether to outsource or to keep activities in-house, and they also decide to outsource the whole department or only one activity. Beside, Wan and Su (2010) indicated that the managers' desired level of outsourcing was higher than the current level. Central to this study is to understand the link between current and desired levels of outsourcing. In other words, how current levels of outsourcing shape future outsourcing tendency. Thus, this study argues that managers' intentions to outsource in the future (desired level of outsourcing) will be significantly related to their current levels of outsourcing. In other words, the higher the current levels of outsourcing, the higher will be the desired levels of outsourcing. The rationale behind this conjuncture is two-fold. On one hand, managers get used to outsourcing. Put it simply, what is outsourced today will be outsourced tomorrow. On the other hand, managers might think that outsourcing is a standardized practice beyond their decision circle, which means future outsourcing is decided on a higher level following current outsourcing. This argument is suggested in the following hypothesis:

Hypothesis 2. There is a significant positive relationship between current level of hotel outsourcing and desired level of hotel outsourcing. 
Furthermore, although hypothesis 1 postulates a direct relationship between managers' perceived benefits and current levels of outsourcing, this study takes a step further and argues that the perceived benefits of outsourcing do not exert a direct effect on desired levels of outsourcing but indirect effect through the mediating role of current levels of outsourcing. The logic behind this argument can be attributed to the fact that 'managers trust their experience'. In other words, if managers experienced positive translations of their perceived benefits with the current levels of outsourcing, they will be willing to outsource in the future, but if managers' perceived benefits did not translate into tangible benefits by their current outsourcing levels, their desire to outsource will be limited. This logic is suggested in the following hypothesis:

Hypothesis 3. Current levels of outsourcing mediate the relationship between the managers' perceived benefits of outsourcing and their desired levels of outsourcing.

\subsection{Moderating effect of perceived risks of outsourcing}

As indicated earlier, outsourcing can bring lots of benefits to the hotel, however it is not without risks (Kim, 2006). Typical concerns that (can) hinder outsourcing or mitigate its benefits include, among others, possible loss of control, loss of confidential information, interruptions of supply, poor quality services, fall in employee morale, loss of internal coherence, and loss of intellectual property rights (Dorasamy et al., 2010; Tomás F. Espinorodríguez \& Robaina, 2005; Hamzah et al., 2010; Hiamey \& Amenumey, 2013; Zhang et al., 2018). From the TCE, outsourcing can entail higher transaction costs compared to inhouse production. This is due to the need to coordinate, monitor, and control the external service provider than the firm's employees (Lamminmaki, 2005, 2007, 2008). According to Power (2006), there are two major types of cost: direct and indirect. Direct costs are usually very tangible and easy to measure, including the cost of conducting the outsourced service. Indirect costs are the expenses an organization must bear but which are difficult to measure. These include items such as legal fees to develop new contracts, employee assistance and displacement fees owing to job reassignment or terminations and communications expenses. In addition to direct and indirect costs, hotels also incur the hidden costs of outsourcing. Hidden 
costs are less tangible in nature and in many cases difficult to measure and report (Aman \& Rahman, 2011; Arshad, May-Lin, Mohamed, \& Affandi, 2007). There are two types of hidden costs related to outsourcing; cost of setting up the contract (including the costs of resolving disputes and discrepancies, meeting with the vendors, negotiations, etc.) which sometimes take a lot of time, and costs of a supplier failing and contracting a new one (Belcourt, 2006; Harland, Knight, Lamming, \& Walker, 2005; Jeffay et al., 1997; Kremic, Icmeli Tukel, \& Rom, 2006; Norman, 2009; Stainburn, 2007; Yildiz \& Demirel, 2014). Hence, the extent to which hotel managers perceive the risks of higher transaction costs is a key deciding factor toward outsourcing. Espino-Rodríguez and Gil-Padilla (2005) indicated that the greater the transaction costs, the greater the costs that information, negotiation and supervision of compliance entail, the less the tendency to outsource the activity. Likewise, Wan and Su (2010) signified that the managers' tendency to outsource more is conditioned to certain challenges such as availability of qualified suppliers. Consequently, following the possible risks that accompany outsourcing, this study contends that the extent to which hotel managers consider outsourcing as a risky action will negatively moderate the relationship between current and desired levels of outsourcing. Put differently, it is essentially expected that the current-desired link should work somewhat differently following the managers' perceived risks of outsourcing. This argument is suggested in the following hypothesis:

Hypothesis 4. Managers' perceived risks of outsourcing negatively moderate the relationship between current and desired levels of outsourcing.

This research extends the previous arguments related to perceived benefits of outsourcing, current levels of outsourcing, desired levels of outsourcing and perceived risks of outsourcing and build our conceptual framework. Fig. 1 depicts the research framework, showing the hypothesized relationships as described above.

\section{INSERT FIGURE 1}




\section{Methods}

\subsection{Sampling and participants}

To test the proposed hypotheses, a random sample of top-level managers working in four and five-star hotels in Egypt were selected. Top-level managers are general managers and department managers who were an appropriate population because they are all involved in the operational and/or decisional issues of outsourcing. Therefore, they were well positioned to provide responses to the survey. Unlike other studies that had covered one single destination, this paper covered two major tourist destinations namely; Cairo and Sharm-Elsheikh. The purposeful selection of these two cities as the geographical area of the population is two-fold:

i) the two cities contain the largest number of hotels with a wide range of characteristics (e.g., category, size) and ii) the chosen cities have different characteristics concerning target markets and availability of external service providers. More precisely, Sharm El-Sheikh is a sun and sand tourist destination located far away from the capital; this might entail certain characteristics of the destination (e.g., seasonality) as well as certain constraints to outsourcing (e.g., limited availability of service providers). On the other side, Cairo does not face extreme seasonality. Further, as the capital of Egypt, Cairo has witnessed the proliferation of firms providing services such as security management and information technology to different service sectors such as banks; the availability of such services is essential for outsourcing. Therefore, they represent an ideal context for the study. Then, a list of four and five-star hotels in both Cairo and Sharm-Elsheikh was developed with the hotel's name, address, and telephone number. This list included 155-hotels in total. The sample frame was adopted from the latest version of Egyptian Hotel Association website (Association, 2012). Thus, the population frame is 155 four- and five-star hotels located in Egypt. Based on Saunders, Lewis, and Thornhill (2009), if the margin of error is selected to be $5 \%$ and the population size is between 150 and 200, then the required sample size is 108-132. Therefore, the survey targeted to reach not less than $30 \%$ by using stratified random sampling. Based on Saunders et al. (2009) 30\% response rate is acceptable when the questionnaire is distributed via email or direct collection. After contacting these hotels, 48-hotels responded to our survey and this represented $31 \%$ response rate.

\subsection{Data collection}


Data was collected through a structured questionnaire. The questionnaire contained four main sections. Section one for measuring the current and desired levels of hotel outsourcing. Section two and three were concerned with measuring the perceived benefits and risks of outsourcing, respectively. While the last section asked about the hotel's profile and respondent's demographics. The questionnaire was administered personally (by the first author). For the sake of reliability, the initial questionnaire was reviewed through a convenience sample of 10-academic experts as well as three practitioners. They were asked to comment on the questionnaire's layout, relevance and appropriateness. Based on their comments, some changes were made such as adding a brief description of each section's objective and reordering the list of hotel activities following the department. Further, the revised questionnaire was piloted by four department managers. After filling the survey, they were asked to comment on clarity and readability of the content. Following their comments, no changes were made in the scales, but few statements were simplified. Participants of the pilot study were not included in further analysis.

The first step in the process was to get permission from Egyptian Ministry of Tourism in order to send the surveys to the hotels in Cairo and Sharm-Elsheikh. The second step involved Ministry of Tourism sending an informed consent e-mail explaining the study purpose, with an attached URL hyperlink to all hotels. The final step was to send a follow-up e-mail to remind hotels managers to complete and submit the survey 1 week and then 1 month after the informed consent e-mail in order to achieve a higher response rate (Richardson 2009). The questionnaire was available online between August 15 and September 2, 2019. The initial e-mails were sent to all 150 hotels, and a total of 137 responses were obtained. The total number of responses was large; hence, the complete case approach was used (Hair et al. 2010) and all responses with missing values (14) were eliminated. Therefore, a total of 123 responses were considered to be valid for further analyses. 


\subsection{Measurements}

To measure the study constructs, scales and items were adopted from the existing validated measures. In order to measure the current and desired levels of outsourcing, a list of hotel activities was developed based on the work of Lamminmaki (2003), Espino-Rodríguez and Padrón-Robaina (2004), Bolat and Yilmaz (2009), Hiamey and Amenumey (2013), and Sani, Dezdar, and Ainin (2013). This list included 32-hotel activity in total. Selection of these activities is based on the extent to which they are commonly outsourced by hotels, and/or the candidacy for future outsourcing. To indicate the current level of outsourcing, managers were asked to determine the extent to which each of the 32 activities are outsourced using a 3-point scale, where (1) means that no part of the operation is outsourced, (2) means partially outsourced, and (3) means totally outsourced to an outside service provider. Similarly, to assess the tendency to outsource, managers were asked to indicate the desired level of outsourcing for each listed activity on a 3-point scale, with (1) means that not desired at all, (2) partially desired, and (3) totally desired to be outsourced in the future. The degree of externalization for each of them is listed in appendix 1 which shows the current and desired levels of outsourcing in hotels.

To measure the perceived benefits of outsourcing a 16-items measure was used. This measure was adapted from Baytok, Soybali, and Zorlu (2013), and Lam and Han (2005). The measure covered different dimensions i.e. quality, financial, organizational and administrative benefits. Similarly, the perceived risks of outsourcing were measured using 13 items that represent the factors that can be obstacles to outsourcing. Those items are developed based on the work of Lam and Han (2005), Maelah et al. (2010) and Baytok et al. (2013). Using a 5point Likert scale (where "1" means strongly disagree and "5" means strongly agree), managers were asked to indicate the extent to which they agree or disagree with each item. Further, this study controlled for a set of variables to partial out their effects. First, firm size, previous studies indicated the broad range of activities undertaken in hotels that pushed them to outsource (Lam \& Han, 2005; Lamminmaki, 2005). In line with previous studies, firm size is measured using the total number of employees. Second, chain affiliation, this is a dichotomous 
variable that takes a value $=1$ when the hotel belongs to a chain and 0 If otherwise. Lastly, this study controls for the hotel category measured as a dichotomous variable that takes a value $=1$ when the hotel is 5-star and 0 If otherwise.

\subsection{Data analysis}

SPSS Version 25 was utilized, in order to test the proposed hypotheses. Several statistical procedures and techniques were applied. First, exploratory data analysis was performed to check the characteristics of our data. Descriptive statistics were conducted to provide an overview of the collected data. Second, the multiple regression analysis assumptions (i.e. normality, linearity) was checked. Then, after checking the assumptions, an assessment and determination of the fit between the specified model and the collected data was made. The proposed hypotheses were tested using Ordinary Least Squares. Further, statistical tests such as the student-t, and F-test were employed. To assess the validity of the scale, Cronbach alphas were computed and found to be above 0.700 indicating that the scales are internally consistent, (see table 1).

\section{INSERT TABLE 1}

\section{Results}

\subsection{Demographics}

The sampled hotels spitted almost equally in terms of category (57\% 4-star and $43 \% 5$ star). Concerning the size, medium sized hotels with 100-299 employees and large sized hotels with 300 employees or more and represented most of the sample with $49 \%$ and $34.5 \%$ respectively. While the remaining $(16.5 \%)$ fall into the small size category with less than 100 employees. The majority of hotels were chain-affiliated $(67.5 \%)$, while $(32.5 \%)$ were independent hotels. Furthermore, the sample was dominated by male respondents $(87.5 \%)$ compared to females (12.5\%). The average age was 37 years. In terms of experience, those with 11-20 years of experience represented (73.5\%), followed by 21-30 years (16.5\%), and 10 years or less $(5 \%)$. As for education, most managers $(83 \%)$ had a university degree, while $11.5 \%$ of them had a high school, and only $5.5 \%$ had a master's degree. 


\subsection{Hypotheses Testing}

Descriptive statistics and bivariate correlations among variables are represented on Table 2, while Tables 3 and 4 represent the results of the regression analysis to test the posited hypotheses. Models 1 and 2 are designed to examine Hypothesis 1 . The following set of models test the mediating effect, and the latter tests the moderating effect. In each set of models, we ran regression with and without control variables.

\section{INSERT TABLE 2}

In models 1 and 2 (Table 3), the relationship is examined between managers' perceived benefits of outsourcing and current levels of outsourcing, as argued in Hypothesis 1. As shown in Model 1, the coefficient is statistically significant and positive $(\beta=0.319 ; \mathrm{p}<0.001)$. Also, in Model 2, where we include control variables, the results remain significant $(\beta=0.284 ; \mathrm{p}<$ 0.001). These results highlight that hypothesis 1 is supported. Accordingly, the overall average mean score obtained from the 16 benefit statements ( $\bar{x}: 4.261$, SD: .582), indicating that the perception of hotel managers towards the effects of outsourcing was favorable and they had benefited from outsourcing their hotel activities.

\section{INSERT TABLE 3}

Model 3 (Table 4) reveals a significant positive relationship between current level and desired level of hotel outsourcing $(\beta=0.816, p<0.001)$, as expected in Hypothesis 2 . In addition, the results (table 2) indicate that the desired outsourcing level was higher than the current outsourcing level where the overall desired outsourcing level ( $\overline{\mathrm{x}}: 1.97)$ was higher than the current outsourcing level ( $\overline{\mathrm{x}}: 1.84)$. Post hoc analysis was conducted to check if there are significant differences between current and desired levels of outsourcing. Using a pairedsample t-test, the results indicate that there is a significant difference in the mean value between the current outsourcing level and the desired outsourcing level (t-statistic $=-8.4219, \mathrm{p}<0.00)$. 
Model 4, Model 5 and Model 6 test the mediating effect of the current level of outsourcing on the relationship between the managers' perceived benefits of outsourcing and their desired levels of outsourcing. Following Baron and Kenny (1986) analytic considerations for mediation, the following four conditions must be met in order to conclude support for Hypotheses 3: (1) managers' perceived benefits of outsourcing must be related to current level of outsourcing, (2) current level of outsourcing must be related to desired level of outsourcing, (3) managers' perceived benefits must be related to desired level of outsourcing in the absence of current level of outsourcing, and (4) the effects of managers' perceived benefits on desired level must be reduced or eliminated upon the inclusion of current level of outsourcing to the model. Model 4 tests the effect of managers' perceived benefits of outsourcing on the desired level of outsourcing $(\beta=0.392, \mathrm{p}<0.001)$. In Model 5, current level of outsourcing is added as an independent variable. Under this condition, benefits of outsourcing become statistically insignificant $(\beta=0.018, p>0.05)$, while current level has a strong positive effect on the desired level of outsourcing $(\beta=0.725, \mathrm{p}<0.001)$. This proves the mediating effect, and therefore the Hypothesis 3 is supported.

\section{INSERT TABLE 4}

Model 7 and Model 8 test the moderating effect of managers' perceived risks on the relationship between current and desired levels of outsourcing. As shown in table 4, the main effect of perceived risks of outsourcing $(\beta=0.061, p>0.05)$, and the interaction effect of current level of outsourcing and perceived risks of outsourcing $(\beta=0.013, \mathrm{p}>0.05)$, are positive and not significant. This result does not support the moderating effect of perceived risks on outsourcing levels. Thus, Hypothesis 4 is not supported.

As for control variables in Models 2, 6 and 8 were all statistically insignificant. This finding suggests that hotel category, firm size, and chain affiliation, while slightly increasing R2, do not make a unit contribution to the model. 


\subsection{Robustness Tests}

The robustness of the findings was tested in several ways. In order to check for multicollinearity, the variance inflation factor was computed, and the average score was 1,379. Since this number is far below 10, it can be concluded that multicollinearity is not present in our models. Also, Durbin-Watson statistic was computed to check for autocorrelation, and the value of 1,99 proves that non-autocorrelation assumption holds. Normality checked showed that our data is normally distributed. Furthermore, to ascertain the results, we re-run the analysis using different combinations of items extracted by the principal component analysis. However, the results did not reveal significant changes.

Finally, it is worth noting that, to limit the potential problems of single respondent bias, all respondents to the survey were senior-level managers at their respective hotels, and therefore are highly qualified to provide accurate responses to the survey items. It was also specified at the beginning of the questionnaire as well as during the interviews that the respondents' anonymity is guaranteed, and data would be used only for research purposes. In addition, the data collected during the interviews was consistent with the survey findings which helped in triangulating the results.

\section{Discussion}

This study was conducted to test the relationship between current and desired levels of outsourcing in the hotel sector. It focuses on modeling the role of managers' perceived benefits and risks on levels of outsourcing. Using a list of 32-hotel activities, managers were asked to indicate their current and desired levels of outsourcing. In testing the hypothesis, the results obtained supported most of the postulated hypotheses. Furthermore, follow up interviews were conducted with participants to shed more light on the benefits and risks of outsourcing from operation managers' point of view. Selected comments from the interviews are included in the managerial implications.

First, this study indicated that hotels in Egypt partially outsource their services and activities. This means that hotels give out selected activities rather than an entire department. For instance, it was found that a hotel outsourced security but not the security manager. This 
specific understanding of outsourcing given by the managers coincides with the definition provided by Broedner, Kinkel, and Lay (2009) who denoted outsourcing as "a vertical scope decision by which only parts of the process are supplied from outside while the process capability to cover the rest remains in-house". This is also in line with Stroh and Treehuboff (2003), in the sense that companies should outsource individual activities rather than an entire department to maintain some in-house expertise.

Second, it was revealed that the managers' perceived benefits of outsourcing positively influence hotels' current levels of outsourcing. In other words, the higher the perceived benefits of outsourcing, the higher the level of outsourced activities by sampled hotels. This agrees with the literature that supported the managers' positive attitude towards outsourcing in hotels (Chatzoglou \& Sarigiannidis, 2009; Espino-Rodríguez \& Padrón-Robaina, 2004; EspinoRodríguez \& Ramírez-Fierro, 2018b). Further, it supports the significant influence of the perceived outsourcing benefits on the outsourcing strategy (Espino-Rodríguez et al., 2012), mainly the level of outsourcing. This positive attitude can be attributed to the benefits obtained from outsourcing selected activities to external service providers (Baytok et al., 2013; Elmuti, 2003; Hemmington \& King, 2000; Zhu, Hsu, \& Lillie, 2001).

Third, hotel managers were also motivated to use outsourcing in the future. This was evident since the overall desired outsourcing level was significantly higher than the current outsourcing level. This finding supports the managers positive inclination towards outsourcing and the tendency to outsource more than at present (Espino-rodríguez \& Robaina, 2005; Wan \& Su, 2010). Nevertheless, there was no direct link between the perceived benefits of outsourcing and the desired level of outsourcing. Instead, the study supported the significant and direct relationship between current and desired level of outsourcing. Thus, although the resourcebased view theory postulates outsourcing as a strategic option (Bustinza, Arias-Aranda, \& Gutierrez-Gutierrez, 2010) that should result from the strategic desire to create and sustain a competitive advantage following a careful evaluation of the company core and non-core activities (Espino-Rodríguez \& Padrón-Robaina, 2005). This study suggests that the desired level of outsourcing is a function of the current level rather than revaluation of the company's 
internal resources following strategic perspective. This contradicts Espino-rodríguez and Robaina (2005) conclusion that although current outsourcing is driven mainly by the cost factor, any future increase in outsourcing will be completely motivated by the strategic factors. Instead, this study suggests that future outsourcing is determined by existing outsourcing, which positions habits or routine as a further explanation for managers' orientation towards future outsourcing. This conjuncture was further supported by the mediating role of current levels of outsourcing between the overall perceived benefits and the desired level of outsourcing. This nascent finding has important implications for the hotel outsourcing literature.

Finally, this study examined the moderating role of the perceived risks of outsourcing on the relationship between current and desired levels of outsourcing. An overall evaluation of the results pointed out that there is a positive but not significant moderating effect. Put differently, the extent to which department managers perceive risks of outsourcing does not significantly moderate the relationship between current and desired levels of outsourcing. This insignificant result is interesting and counterintuitive since it contradicts the existing literature around the negative role of perceived risks on managers attitude towards outsourcing (EspinoRodríguez \& Ramírez-Fierro, 2018). However, this result can be attributed to several reasons which are not mutually exclusive. First, the effect of perceived risks on outsourcing may not be detrimental for all managers/hotels. Put simply, based on their own experience, managers perceive risks differently which weaken the overall perceived risks of outsourcing. Also, both outsourcing decision and carrying on the activities in-house have risks (Power, 2006). Secondly, despite the risks related to outsourcing, managers perceive limited control over future outsourcing decisions which might be determined in a higher strategic level especially in chains or independent hotels where outsourcing decisions are made in the corporate level (Espino-Rodríguez \& Ramírez-Fierro, 2018b). Lastly, managers become familiar with the activities that they get used to outsourcing overtime. Such familiarity might undermine the strength of the perceived risks.

\section{Conclusion and Implications}




\subsection{Theoretical implications}

This study takes the first step in modeling and testing the outcomes of outsourcing from the point of view of operational managers. The obtained results complement both decision making dynamics and hotel outsourcing research by shedding light on how outsourcing decisions are framed and to what extent operational managers in hotels perceive their role in shaping future decisions. The results showed that perceived risks and benefits play a limited or indirect role in shaping future outsourcing decisions, while the current outsourced activities are the main determinant of future outsourcing. This limited role of cognitive evaluations (perceived benefits and risks) in shaping future outsourcing decisions may initiate that outsourcing decisions becomes habitual overtime in the sense that outsourcing a given activity (i.e., pest control, security) repeatedly in a stable context leads to automatic and habitual outsourcing overtime with limited cognitive re-evaluations of alternatives. Such speculation needs further investigations but indeed has important implications for both theory and practice. Another interpretation goes in line with Espino-Rodríguez and Ramírez-Fierro (2018b) who argued that "outsourcing strategies are often imposed on hotel managers" which highlights the limited role of operation managers and employees in outsourcing strategies especially in a chain or individual hotels where the decisions are made at the corporate or director levels. Such speculation was confirmed where the statistical analysis revealed limited and non-significant role for managers' perceived benefits and risks in shaping future outsourcing.

\subsection{Managerial implications}

On the managerial side, this study has the potential to inform management practitioners about successful outsourcing. First, the study showed the positive attitude toward outsourcing from operation managers' point of view. This was also supported by managers' verbal comments collected during the interviews. A respondent indicated that outsourcing can result in an initial cash saving (e.g., cash that will not have to be invested in the overhaul of existing laundry equipment). Further, controlling the budget and predictable income were also other

cited benefits for outsourcing in the sense that outsourcing allows hotels to estimate the exact budget because the outsourcing contract declares a predictable income within a defined time 
frame. Outsourcing helped also to reduce staff costs since the outsourcing company can be responsible for employees' salaries, uniform, insurance and other benefits, in addition to recruiting, hiring and training. Therefore, hotels can also reduce the cost of recruiting and training new employees, employee welfare, and compensation for external employees because it is the outsourcing provider's responsibility to invest in those activities. With regard to the latter, for instance, Belcourt (2006) indicated that specialized suppliers are more efficient because they divide the costs of training personnel, undertaking research and development across more users. In similar vein, Sriwongwanna (2009) highlighted that hotels can reduce the budget by avoiding the costs of job advertisements and training new employees. Further, these sentiments are clearly expressed by the following managers' comments:

"The concessionaire undertakes to equip the shop, with all necessary equipment" (Director of Sales).

"I guess the main thing that leads to outsourcing is that you can get better service for perhaps the same money of doing the function in-house" (General Manager).

". . . we can easily control the budget because we know in advance the cost of security and the income from the health club" (F\&B Manager).

Second, despite the insignificant impact of perceived outsourcing risks on the currentdesired outsourcing relationship, managers articulated various risks related to outsourcing for example; poor service quality was highlighted by a respondent who had to change several pest control management companies in a short period of time. This concern agrees with Knox (2010) where managers complained about the low-quality standards of outsourced staff. Concurrently, another view signified that this barrier is not related to all services and might vary based on the outsourced activity. Furthermore, the participants also referred to other risks related to outsourcing such as cultural differences between the hotel and the external entity, and loyalty and commitment of external employees. These views can be noted from the following comments:

"They (pest control companies) used to start with high quality standards and certified pesticides and within a very short time they started to exchange these products with low quality materials" (Director of Sales). 
"Hiring unqualified staff is expected in areas such as security staff, but it is not the issue when it comes to spa services, since the provider is a specialist with a famous brand" (Director of Marketing)

"The kind of culture that is associated with the outsourced staff might be different from the culture we are building. Therefore, sometimes there are conflicts. What is ok to be done in other companies or even the agency might not be ok with us but the person coming from that agency might think it is ok because that is how things were done or are done in that company" (General Manager).

"Because they are not your employees, we struggle with the loyalty, the commitment of the people. That is why sometimes we have a little problem" (Sales and Marketing Director).

On the other hand, although confidentiality and being worried about hotel's confidential information was considered by many researchers as a reason for not outsourcing hotel activities (Promsivapallop, 2009; Wan \& Su, 2010), in this study, many respondents did not consider this issue as a risk of outsourcing, which can be attributed to the fact that most hotels were engaged in forms of complementary or non-core activity (Espino-Rodríguez \& PadrónRobaina, 2005) outsourcing such as pest control, security and transportation that have limited access to hotels' confidential information. It should also be noted that many of the discussed risks may not be related to 'outsourcing' itself but the way it was applied. Therefore, many of these risks can be avoided if the hotel selects the appropriate partner. More importantly, future outsourcing decisions should be discussed in direct link with operation managers. Although managers showed inclination towards outsourcing in general, they also showed less control over desired outsourcing levels. Therefore, a two-way communication should be strengthened between top management (chains) and the department managers to improve mutual understanding and develop a relationship of trust.

\subsection{Limitations and future research}

Despite its contributions, this study has some limitations. First, although the sample size was above $30 \%$ of the total population, the findings are based on one country. So, the generalization of results should be taken with caution. Second, the benefits/risks of outsourcing were measured using self-reported measures and perceived results rather than actual results. 
Hence, future research can consider financial metrics to compare with objective evaluations. Lastly, the study was confined to four- and five-star hotels. Despite being justified, our findings are not generalizable to lower quality or smaller hotels. Therefore, future studies should also extend to other hotel categories.

\section{References}

Altin, M., Uysal, M., \& Schwartz, Z. (2018). Revenue Management Outsourcing: A Hybrid Model of Transaction Cost Economics and Organizational Capability. Cornell Hospitality Quarterly, 59(2), 112-124.

Aman, A., \& Rahman, E. (2011). Managing relational risks in accounting outsourcing: Experiences of small firm. World Applied Sciences Journal, 15(1), 56-62.

Arshad, N. H., May-Lin, Y., Mohamed, A., \& Affandi, S. (2007). Inherent risks in ICT outsourcing project. Paper presented at the Proceeding of the 8th WSEAS Conference.

Association, E. H. (2012). Egyptian hotel guide. The 23rd Edition Egyptian Hotel Association. Cairo, 166-209.

Barney, J. (2001). Resource-based theories of competitive advantage: A ten-year retrospective on the resource-based view. Journal of management, 27(6), 643-650.

Baron, R. M., \& Kenny, D. A. (1986). The moderator-mediator variable distinction in social psychological research: Conceptual, strategic, and statistical considerations. Journal of personality and social psychology, 51(6), 1173.

Barthélemy, J. (2003). The seven deadly sins of outsourcing. Academy of Management Perspectives, 17(2), 87-98. doi: 10.5465/ame.2003.10025203

Baytok, A., Soybali, H. H., \& Zorlu, O. (2013). Outsourcing in Thermal Hotel Enterprises: The Case of Turkey. Business Management Dynamics, 3(5), 1-14.

Belcourt, M. (2006). Outsourcing-The benefits and the risks. Human resource management review, 16(2), 269-279.

Bolat, T., \& Y1lmaz, Ö. (2009). The relationship between outsourcing and organizational performance: is it myth or reality for the hotel sector? International Journal of Contemporary Hospitality Management, 21(1), 7-23.

Broedner, P., Kinkel, S., \& Lay, G. (2009). Productivity effects of outsourcing: new evidence on the strategic importance of vertical integration decisions. International Journal of Operations \& Production Management, 29(2), 127-150.

Bustinza, O., Arias-Aranda, D., \& Gutierrez-Gutierrez, L. (2010). Outsourcing, competitive capabilities and performance: an empirical study in service firms. International Journal of Production Economics, 126(2), 276-288.

Chatzoglou, P. D., \& Sarigiannidis, L. (2009). Business outsourcing and organisational performance: The case of the Greek hotel industry. International Journal of Services Technology and Management, 11(2), 105-127.

Chun-Lai, P., Espino-Rodríguez, T. F., \& Baum, T. (2019). Do relational norms matter in outsourcing relationships? Lesson learned from hotel sectors. Tourism Economics, 25(2), 189-212.

Dorasamy, M., Marimuthu, M., Jayabalan, J., Raman, M., \& Kaliannan, M. (2010). CRITICAL FACTORS IN OUTSOURCING OF ACCOUNTING FUNCTIONS IN MALAYSIAN SMALL MEDIUM-SIZED ENTERPRISES (SMEs). Kajian Malaysia: Journal of Malaysian Studies, 28(2). 
El-Houshy, S. S., El-Dmerdash, J. M., \& El-Said, O. A. (2015). Investigating Hotel Outsourcing in the Egyptian Hotel Market: Reasons, Barriers and Activities. Journal of Faculty of Tourism and Hotels, 12(2), 48-72.

Elmuti, D. (2003). The perceived impact of outsourcing on organizational performance. American Journal of business, 18(2), 33-42.

Espino-Rodríguez, T., \& Ramírez-Fierro, J. (2018). Outsourcing Performance in Hotels: Evaluating Partnership Quality. Sustainability, 10(8), 2766.

Espino-Rodríguez, T. F., \& Gil-Padilla, A. M. (2005). The relationship between leisure outsourcing and specificity: performance and management perception in hotels in the Canary Islands. Journal of Hospitality \& Tourism Research, 29(3), 396-418.

Espino-Rodríguez, T. F., \& Gil-Padilla, A. M. (2007). The impact of outsourcing strategies on information systems capabilities in the hotel industry. The Service Industries Journal, 27(6), 757-777.

Espino-Rodríguez, T. F., \& Lai, P. C. (2014). Activity outsourcing and competitive strategy in the hotel industry. The moderator role of asset specificity. International Journal of Hospitality Management, 42, 9-19.

Espino-Rodríguez, T. F., Lai, P. C., \& Baum, T. (2012). Risks and benefits of outsourcing hotel operations: A comparison between Scotland and Taiwan. Tourism Economics, 18(1), 95-120.

Espino-Rodríguez, T. F., \& Padrón-Robaina, V. (2005). A resource-based view of outsourcing and its implications for organizational performance in the hotel sector. Tourism management, 26(5), 707-721.

Espino-Rodríguez, T. F., \& Padrón-Robaina, V. c. (2004). Outsourcing and its impact on operational objectives and performance: a study of hotels in the Canary Islands. International Journal of Hospitality Management, 23(3), 287-306.

Espino-Rodríguez, T. F., \& Ramírez-Fierro, J. C. (2018a). THE INTENSITY OF HOTEL OUTSOURCING AND ITS PERCEIVED BENEFITS AND RISKS. Cuadernos de Turismo(41), 661-664.

Espino-Rodríguez, T. F., \& Ramírez-Fierro, J. C. (2018b). Managers' attitudes toward hotel outsourcing in a tourist destination. An approach from the benefits and risks perspective. Tourism management perspectives, 26, 143-152.

Espino-rodríguez, T. F., \& Robaina, V. P. (2005). The management perception of the strategic outsourcing of services: An empirical examination in the hotel sector. The Service Industries Journal, 25(5), 689-708. doi: 10.1080/02642060500101047

Espino-Rodríguez, T. F., \& Gil-Padilla, A. M. (2005). Determinants of information systems outsourcing in hotels from the resource-based view: An empirical study. International Journal of Tourism Research, 7(1), 35-47.

Gilley, K. M., Greer, C. R., \& Rasheed, A. A. (2004). Human resource outsourcing and organizational performance in manufacturing firms. Journal of business research, 57(3), 232-240.

Gilley, K. M., \& Rasheed, A. (2000). Making more by doing less: an analysis of outsourcing and its effects on firm performance. Journal of management, 26(4), 763-790.

Gonzalez, R., Llopis, J., \& Gasco, J. (2011). What do we know about outsourcing in hotels? The Service Industries Journal, 31(10), 1669-1682.

Green, K. W., Chakrabarty, S., \& Whitten, D. (2007). Organisational culture of customer care: market orientation and service quality. International Journal of Services and Standards, 3(2), 137-153.

Hamzah, N., Aman, A., Maelah, R., Auzair, S. M., \& Amiruddin, R. (2010). Outsourcing decision processes: A case study of a Malaysian firm. African Journal of Business Management, 4(15), 3307-3314. 
Harland, C., Knight, L., Lamming, R., \& Walker, H. (2005). Outsourcing: assessing the risks and benefits for organisations, sectors and nations. International Journal of Operations \& Production Management, 25(9), 831-850.

Hemmington, N., \& King, C. (2000). Key dimensions of outsourcing hotel food and beverage services. International Journal of Contemporary Hospitality Management, 12(4), 256-261.

Hiamey, S. E., \& Amenumey, E. K. (2013). Exploring service outsourcing in 3-5 Star hotels in the Accra Metropolis of Ghana. Tourism Management Perspectives, 8, 9-17.

Jeffay, J., Bohannon, S., \& Laspisa, E. K. (1997). Beyond benefits: The changing face of HR outsourcing. Benefits Quarterly, 13(1), 41.

Kim, B.-M. (2006). Convention services manager's perception of the strategic outsourcing of convention services.

Knox, A. (2010). 'Lost in translation': An analysis of temporary work agency employment in hotels. Work, employment and society, 24(3), 449-467.

Kremic, T., Icmeli Tukel, O., \& Rom, W. O. (2006). Outsourcing decision support: a survey of benefits, risks, and decision factors. Supply Chain Management: an international journal, 11(6), 467482.

Lam, T., \& Han, M. X. (2005). A study of outsourcing strategy: a case involving the hotel industry in Shanghai, China. International Journal of Hospitality Management, 24(1), 41-56.

Lamminmaki, D. (2003). Outsourcing in the hotel industry: A management accounting perspective. Griffith University, Gold Coast, Australia.

Lamminmaki, D. (2005). Why do hotels outsource? An investigation using asset specificity. International Journal of Contemporary Hospitality Management, 17(6), 516-528.

Lamminmaki, D. (2007). Outsourcing in Australian hotels: a transaction cost economics perspective. Journal of Hospitality \& Tourism Research, 31(1), 73-110.

Lamminmaki, D. (2008). Accounting and the management of outsourcing: An empirical study in the hotel industry. Management accounting research, 19(2), 163-181.

Lamminmaki, D. (2011). An examination of factors motivating hotel outsourcing. International Journal of Hospitality Management, 30(4), 963-973.

Letica, M. (2016a). The effect of outsourcing activities selection on the benefits of outsourcing. Management: journal of contemporary management issues, 21(2), 77-97.

Letica, M. (2016b). The effect of outsourcing activities selection on the benefits of outsourcing. Management-Journal of Contemporary Management Issues, 21(2), 77-97.

Maelah, R., Aman, A., Hamzah, N., Amiruddin, R., Sofiah, \& Auzair, M. (2010). Accounting outsourcing turnback: process and issues. Strategic Outsourcing: An International Journal, $3(3), 226-245$.

Norman, T. J. (2009). Outsourcing Human Resource activities: measuring the hidden costs and benefits.

Power, M. (2006). The outsourcing handbook: how to implement a successful outsourcing process: Kogan Page Publishers.

Promsivapallop, P. (2009). A critical evaluation of transaction cost economics applied to outsourcing in the hotel industry in Thailand. University of Surrey (United Kingdom).

Rothery, B., Robertson, I. (1995). The Truth About Outsourcing. Hampshire, UK: Gower Publishing.

Sani, A., Dezdar, S., \& Ainin, S. (2013). Outsourcing patterns among Malaysian hotels. International Journal of Business and Social Science, 4(9).

Saunders, M., Lewis, P., \& Thornhill, A. (2009). Research methods for business students. Essex. Financial Times/Prentice Hall.

Sharma, A., Moon, J., Baig, J. I., Choi, J.-G., Seo, K., \& Donatone, L. C. (2015). Cost-benefit framework for K-12 foodservice outsourcing decisions. International Journal of Hospitality Management, 45, 69-72. 
Sriwongwanna, J. (2009). Understanding the impact of outsourcing human resource activities on employee attitudes and behaviours. Murdoch University.

Stainburn, S. (2007). HR: Outsource or in-house: It is been nothing but a benefit for us. Crain's Chicago Business, 30(41), 39.

Stroh, L. K., \& Treehuboff, D. (2003). Outsourcing HR functions: When-and when not-to go outside. Journal of Leadership \& Organizational Studies, 10(1), 19-28.

Wan, C.-S., \& Su, A. Y.-L. (2010). Exploring the factors affecting hotel outsourcing in Taiwan. Asia Pacific Journal of Tourism Research, 15(1), 95-107.

Wieske, J. P. a. T. (2018). Quality Management \& Controlling, Outsourcing. Retrieved 01-12-2018, 2018 , from https://gc21.giz.de/ibt/en/opt/site/ilt/ibt/regionalportale/sadc/inhalt/logistics/module_04/3_o utsourcing.html

Williamson, O. E. (1981). The Economics of Organization: The Transaction Cost Approach. American journal of sociology, 87(3), 548-577. doi: 10.1086/227496

Williamson, O. E. (2008). OUTSOURCING: TRANSACTION COST ECONOMICS AND SUPPLY CHAIN MANAGEMENT*. Journal of Supply Chain Management, 44(2), 5-16. doi: 10.1111/j.1745-493X.2008.00051.x

Yildiz, S., \& Demirel, Z. H. (2014). The benefits, risks and effects on performance of the outsourcing: A comparative study of seasonal and permanent hotels. Procedia-Social and Behavioral Sciences, 109, 514-521.

Zaitseva, N., Somova, T., Larionova, A., Gornostaeva, Z., Eliseeva, O., Tepina, J., \& Ryabokon, N. (2017). Evaluation of the socio-economic benefits from the use of outsourcing in the service and. Eurasian Journal of Analytical Chemistry, 12(7), 1183-1191.

Zhang, Y., Ma, E., \& Qu, H. (2018). Transaction cost and resources based views on hotels' outsourcing mechanism: an empirical study in China. Journal of Hospitality Marketing \& Management, 27(5), 583-600.

Zhu, Z., Hsu, K., \& Lillie, J. (2001). Outsourcing-a strategic move: the process and the ingredients for success. Management Decision, 39(5), 373-378. 
Table 1 . The reliability test results of the scales used in the study

\begin{tabular}{|l|c|}
\hline Questionnaire constructs & Cronbach's Alpha \\
\hline Levels of outsourcing & 0.893 \\
\hline Perceived benefits of outsourcing & 0.871 \\
\hline Perceived risks of outsourcing & 0.816 \\
\hline Total scale reliability & 0.847 \\
\hline
\end{tabular}

Table 2. Descriptive statistics and correlations

\begin{tabular}{|c|c|c|c|c|c|c|c|c|c|c|c|}
\hline Variable & Mean & S.D. & Min. & Max. & 1 & 2 & 3 & 4 & 5 & 6 & 7 \\
\hline $\begin{array}{l}\text { Desired level } \\
\text { of outsourcing }\end{array}$ & 1.9730 & 0.1956 & 1.58 & 2.64 & 1.000 & & & & & & \\
\hline $\begin{array}{l}\text { Managers' } \\
\text { perceived } \\
\text { benefits of } \\
\text { outsourcing }\end{array}$ & 4.2617 & 0.5819 & 2.82 & 4.98 & $0.587 * * *$ & 1.000 & & & & & \\
\hline $\begin{array}{l}\text { Current level } \\
\text { of outsourcing }\end{array}$ & 1.8491 & 0.2614 & 1.50 & 2.45 & $0.619 * * *$ & $0.719 * * *$ & 1.000 & & & & \\
\hline $\begin{array}{l}\text { Risks of } \\
\text { outsourcing }\end{array}$ & 3.6083 & 0.5836 & 2 & 4.73 & $0.464 * *$ & $0.327 *$ & $0.404 *$ & 1.000 & & & \\
\hline Firm size & 2.45 & 0.7194 & 1 & 3 & $0.284^{*}$ & $0.361 *$ & $0.373 *$ & 0.120 & 1.000 & & \\
\hline $\begin{array}{l}\text { Hotel } \\
\text { category }\end{array}$ & 2.45 & 0.7194 & 1 & 2 & $0.271 *$ & $0.309 *$ & $0.381 *$ & 0.135 & $0.428 * *$ & 1.000 & \\
\hline $\begin{array}{l}\text { Chain- } \\
\text { affiliated }\end{array}$ & 1.927 & 0.5210 & 1 & 2 & -0.047 & 0.051 & -0.052 & -0.048 & 0.075 & 0.270 & 1.000 \\
\hline
\end{tabular}

$N=123$

significance: $* * * p<0.001 ; * * p<0,01 ; * p<0.05$

Table 3. Regression results estimating the effects of managers' perceived benefits of outsourcing on the current level of outsourcing 


\section{Dependent variable: current level of outsourcing}

\begin{tabular}{|c|c|c|}
\hline & Model 1 & Model 2 \\
\hline $\begin{array}{l}\text { Managers' perceived benefits of } \\
\text { outsourcing }\end{array}$ & $\begin{array}{l}0.319 * * * \\
(0.020)\end{array}$ & $\begin{array}{l}0.284 * * * \\
(0.017)\end{array}$ \\
\hline Firm size & 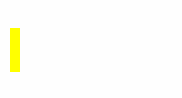 & $\begin{array}{l}0.051 \\
(0.040)\end{array}$ \\
\hline Hotel category & 1 & $\begin{array}{l}0.038 \\
(0.024)\end{array}$ \\
\hline Chain-affiliated & 1 & $\begin{array}{l}-0.049 \\
(0.016)\end{array}$ \\
\hline Constant & $\begin{array}{l}0.851 * * * \\
(0.139)\end{array}$ & $\begin{array}{l}0.837 * * * \\
(0.130)\end{array}$ \\
\hline R-sq. & 0.609 & 0.621 \\
\hline $\mathrm{F}$ & $48.481 * * *$ & $11.390 * * *$ \\
\hline
\end{tabular}

Table 4. Regression results estimating the effects of managers' perceived benefits of outsourcing, current level of outsourcing, and risks of outsourcing on desired level of outsourcing

\section{Dependent variable: desired level of future outsourcing}

\begin{tabular}{|c|c|c|c|c|c|c|}
\hline & \multicolumn{4}{|c|}{ mediating effect } & \multicolumn{2}{|c|}{ moderating effect } \\
\hline & Model 3 & Model 4 & Model 5 & Model 6 & Model 7 & Model 8 \\
\hline $\begin{array}{l}\text { Managers' } \\
\text { perceived benefits } \\
\text { of outsourcing }\end{array}$ & I & $\begin{array}{l}0.392 * * * \\
(0.061)\end{array}$ & $\begin{array}{l}0.039 \\
(0.047)\end{array}$ & $\begin{array}{l}0.018 \\
(0.062)\end{array}$ & - & - \\
\hline $\begin{array}{l}\text { Current level of } \\
\text { outsourcing }\end{array}$ & $\begin{array}{l}0.816 * * * \\
(0.063)\end{array}$ & 1 & $\begin{array}{l}0.710 * * * \\
(0.029)\end{array}$ & $\begin{array}{l}0.725 * * * \\
(0.057)\end{array}$ & $\begin{array}{l}0.749 * * * \\
(0.062)\end{array}$ & $\begin{array}{l}0.740 * * * \\
(0.069)\end{array}$ \\
\hline $\begin{array}{l}\text { Risks of } \\
\text { outsourcing }\end{array}$ & & 1 & & - & $\begin{array}{l}0.074 \\
(0.051)\end{array}$ & $\begin{array}{l}0.061 \\
(0.049)\end{array}$ \\
\hline
\end{tabular}




\begin{tabular}{|c|c|c|c|c|c|c|}
\hline $\begin{array}{l}\text { Current level of } \\
\text { outsourcing x risks } \\
\text { of outsourcing }\end{array}$ & & & & - & $\begin{array}{l}0.014 \\
(0.017)\end{array}$ & $\begin{array}{l}0.013 \\
(0.027)\end{array}$ \\
\hline Firm size & 1 & 1 & 1 & $\begin{array}{l}-0.019 \\
(0.046)\end{array}$ & $\|$ & $\begin{array}{l}0.008 \\
(0.056)\end{array}$ \\
\hline Hotel category & 1 & 1 & 1 & $\begin{array}{l}-0.016 \\
(0.041)\end{array}$ & 1 & $\begin{array}{l}-0.016 \\
(0.059)\end{array}$ \\
\hline Chain-affiliated & 1 & $\|$ & 1 & $\begin{array}{l}-0.017 \\
(0.048)\end{array}$ & 1 & $\begin{array}{l}-0.010 \\
(0.063)\end{array}$ \\
\hline Constant & $0.619 * *$ & $1.180 * * *$ & $0.579 * *$ & $0.617 * *$ & $0.401 * *$ & 0.418 \\
\hline R-sq. & 0.705 & 0.490 & 0.726 & 0.728 & 0.804 & 0.817 \\
\hline $\mathrm{F}$ & $114.370 * * *$ & $49.309 * * *$ & $53.784 * * *$ & $21.946^{* * *}$ & $41.536^{* * *}$ & $19.830 * * *$ \\
\hline
\end{tabular}

